\title{
JURNAL
}

\section{Karakteristik Bending Struktur Berlapis dengan Inti Berbentuk Gelombang Trapezoidal Dua Arah}

\author{
Marsono, Fery Hidayat, Gregorius P. Purap \\ Teknik Mesin Institut Teknologi Nasional Bandung, Indonesia \\ Jl. PKH. Mustapha No. 23, Bandung 40124 \\ Email : marsono@itenas.ac.id
}

\begin{abstract}
Abstrak
Struktur berlapis berbahan FRP memiliki performa yang baik dalam hal bobot yang ringan serta kekuatan yang tinggi. Struktur berlapis juga memiliki kemampuan untuk melindungi penumpang dari luka serius ketika terjadi kecelakaan (tabrakan). Hal ini memberikan alasan mengapa struktur ini sangat dibutuhkan pada sektor transportasi. Penelitian ini diarahkan untuk mendapatkan metoda pembuatan sturktur berlapis dengan inti berbentuk gelombang trapezoidal dua arah yang paling sederhana. Penelitian ini juga bertujuan untuk mendapatkan karakeristik bending dari sturktur berlapis dengan inti berbentuk gelombang trapezoidal dua arah yang berupa angka kekuatan bending serta angka kekakuan melalui uji bending. Bahan yang digunakan untuk membuat specimen panel struktur berlapis ini adalah bahan komposit serat kaca. Spesimen panel struktur berlapis dibuat dengan dua variasi jenis serat kaca, yaitu WR400 dan WR600 serta dua variasi ketebalan dinding inti struktur berlapis, yaitu yang dibuat dengan 1 lapis dan 2 lapis serat kaca. Pengujian bending yang dilakukan menunjukkan bahwa angka kekuatan bending tertinggi yang dapat dicapai struktur berlapis ini adalah sebesar $3,920 \mathrm{kgf} / \mathrm{mm}^{2}$ yang ditunjukkan oleh struktur berlapis dengan inti struktur yang dibuat dengan 2 lapis bahan serat kaca WR600. Spesimen yang sama juga menunjukkan angka kekakuan tertinggi, yaitu dan 55,6 kgf $/ \mathrm{mm}$.
\end{abstract}

Kata kunci:

Struktur berlapis, inti gelombang, komposit serat kaca, kekuatan bending, kekakuan

\section{Abstract}

Sandwich structure made of FRP has a good performance in term of light weight and high strength. Sandwich structure is also has ability to protect passenger from serious injury in the case of accident (crash). This is the reason why the sandwich structure is needed in the transportation sector. This research is focused to find a simplest method of making a sandwich structure with a two-directional trapezoidal corrugated core. This research is also aims to obtain the bending behaviour of the sandwich structure with a two-directional trapezoidal wave core, such as flexural stength and stiffness value through the bending test. Material that is used to make the panel specimens of the sandwich structure is fiberglass composite. Panel specimens were made with two variation of fiberglass woven, which is WR400 and WR600, and variations in thickness of structure core wall, which are made by 1 layer and 2 layer of fiberglass. The bending test that have been performed shows that the the highest flexural strength that can be achieved by this sandwich structure is 3,920 kgf/mm², which is showed by the sandwich structure with a core made with 2 layers of WR600 fiberglass. The same specimen also showed the highest stiffness value of $55.6 \mathrm{kgf} / \mathrm{mm}$.

Keywords:

Sandwich structure, corrugated core, fiberglass composite, flexural strength, stiffness 


\section{Pendahuluan}

Rekayasa di bidang material telah menghasilkan suatu material yang dibangun secara bertumpuk dari beberapa lapisan, yaitu material dengan struktur sandwich. Material dengan struktur berlapis (sandwich structure) ini dikembangkan dengan salah satu tujuannya yaitu untuk mendapatkan material dengan bobot yang ringan (light weight) dengan kekuatan (strength) dan kekakuan (stiffness) yang tinggi. Material dengan performa seperti ini cocok dterapkan pada pesawat terbang, kapal laut dan transportasi darat.

Corrugated-core sandwich adalah salah satu bentuk material dengan struktur berlapis (sandwich) dengan inti berbentuk gelombang (corrugated). Material ini tersusun dari inti (core) yang berbentuk gelombang yang berada di antara dua lembar kulit (skin) yang tipis. Inti berbentuk gelombang menciptakan jarak di antara dua lembaran kulit serta mengunci kestabilan di antara bagian inti dan kulit, hingga menjadikan struktur ini seolah-olah seperti pelat tunggal yang tebal [1]. Konsep material dengan struktur berlapis dengan inti berbentuk gelombang telah diperkenalkan sejak awal abad 20 dengan beberapa variasi bentuk. Bentuk inti gelombang yang paling sering digunakan adalah bentuk sinusoidal dan trapezoidal. [2].

Sebagaimana umumya material dengan struktur sandwich, struktur berlapis dengan dengan inti berbentuk gelombang ini juga memiliki kelebihan dalam hal rasio kekuatan terhadap berat (strength-to-weight ratio) yang tinggi. Beberapa percobaan yang telah dilakukan menunjukkan bahwa strruktur berlapis dengan inti berbentuk gelombnag trapezoidal memiliki kekuatan untuk menahan beban tekan (compression) dan beban geser (shear). Bentuk ini juga memiliki rasio kekakuan bending terhadap berat (flexural stiffness-to-weight ratio) yang tinggi [3].

Stuktur berlapis dengan inti berbentuk gelombang ini juga memiliki keistimewaan lain, yaitu karakteristik crashworthiness yang baik di samping kemampuannya menahan benturan (impact resisteance). Crashworthiness adalah kemampuan struktur untuk melindungi penumpang ketika terjadi tabrakan (crash). Karakteristik crashworthiness yang baik sangat diperlukan pada struktur kendaraan, tertutama kendaraan yang berfungsi mengangkut penumpang. Kemampuan ini didapatkan terutama dari ikatan yang kuat di antara inti berbentuk gelombang dan kulit. Sebagian besar kemampuan ini terkait dengan parameter bentuk dan dimensi dari inti struktur sandwich [4].

Pemanfaatan bahan FRP (Fibre Reinforce Polymer) untuk membuat struktur berlapis telah dimulai sejak akhir abad 20, setelah sebelumnya struktur berlapis dibuat dengan menggunakan bahan logam secara keseluruhan. Penggunaan bahan komposit untuk membuat strukur berlapis dilakukan untuk mendapatkan keuntungan ganda, yaitu mendapatkan specific flexural rigidity yang tinggi dari konsep struktur berlapis serta mendapatkan keuntungan dalam hal bobot yang ringan dari penggunaan material FRP. Material FRP juga memiliki kelebihan dalam hal kemampuan menghasilkan bentuk yang kompleks dan perakitan yang lebih mudah [2].

Penelitian ini dilakukan dengan pertimbangan segala kelebihan yang dimiliki struktur berlapis dengan inti berbentuk gelombang, terutama kesesuaian aplikasinya untuk kendaraan. Dalam penelitian ini dibuat dan diuji panel struktur berlapis dengan inti berbentuk gelombang trapezoidal ke dua arah, yang mana panel struktur berlapis ini nantinya akan diaplikasikan untuk panel badan mobil hemat energi. Penelitian ini juga bertujuan untuk menemukan proses pembuatan struktur berlapis dengan bentuk gelombang trapezoidal ke dua arah dengan cara yang sederhana dan bisa dilakukan secara manual. Bahan yang digunakan untuk membuat panel struktur berlapis ini adalah bahan komposit serat kaca dengan matriks resin. Panel struktur berlapis akan diuji dengan metoda uji bending terutama untuk mengetahui kekuatan bending serta kekakuan dari panel struktur berlapis tersebut. 


\section{Metodologi Penelitian}

\subsection{Rancangan struktur berlapis}

Struktur berlapis yang dibuat dan diuji pada penelitian ini memiliki inti berbentuk gelombang yang mendekati bentuk trapezoidal dan gelombang trapezoidal ini dibentuk ke dua arah, yaitu atah memanjang dan arah melintang. Spesimen panel struktur sandwich pada awalnya dibuat dengan ukuran panjang $200 \mathrm{~mm}$, lebar $200 \mathrm{~mm}$ dan ketebalan panel kira-kira $10 \mathrm{~mm}$. Bentuk rancangan panel struktur berlapis dengan inti berbentuk gelombang terlihat pada gambar 1

Bahan yang digunakan untuk membuat struktur berlapis ini adalah bahan komposit serat kaca (fiberglass) dengan matriks resin. Spesimen panel struktur berlapis dibuat dengan beberapa variasi, yaitu variasi serat kaca yang digunakan dan variasi jumlah lapisan yang digunakan pada inti struktur berlapis. Serat kaca yang digunakan terdiri dari dua macam, yaitu WR400 dan WR600. Bagian inti struktur juga dibuat dengan dua variasi lapisan serat kaca, yaitu 1 lapis dan 2 lapis serat kaca. Lapisan kulit (skin) untuk semua spesimen panel struktur sandwich dibuat dengan menggunakan 1 lapis serat kaca WR 400. Matriks yang digunakan pada komposit ini adalah resin SHCP 2668 CM-M.

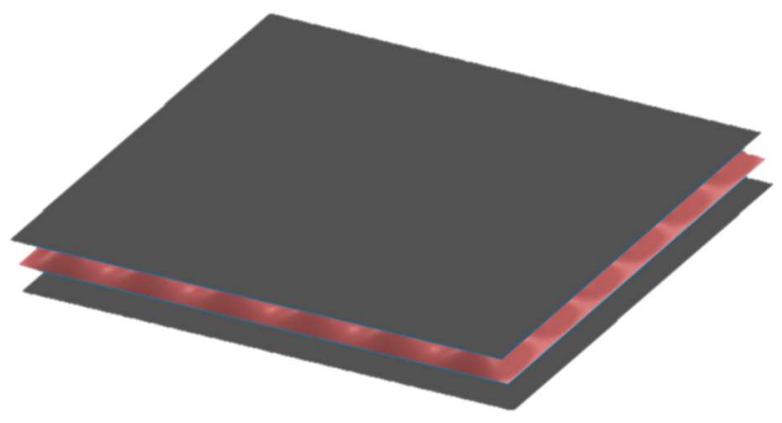

Gambar 1. Rancangan Panel struktur berlapis dengan inti berbentuk gelombang

\subsection{Proses pembuatan}

Inti dari struktur berlapis adalah kunci dari performa yang akan ditampilkan oleh sebuah struktur berlapis, oleh karena itu inti struktur harus dibuat dengan benar. Teknik hand lay-up menjadi pilihan untuk membuat inti berbentuk gelombang karena metoda ini dapat dilakukan secara manual dengan mudah serta menghasilkan penyerapan resin ke dalam serat dengan baik. Untuk menjaga konsistensi bentuk dan ukuran dari inti berbentuk gelombang ini, penggunaan cetakan adalah pilihan yang tepat. Cetakan yang digunakan pada pembuatan inti berbentuk gelombang ini terlihat pada gambar 2 .

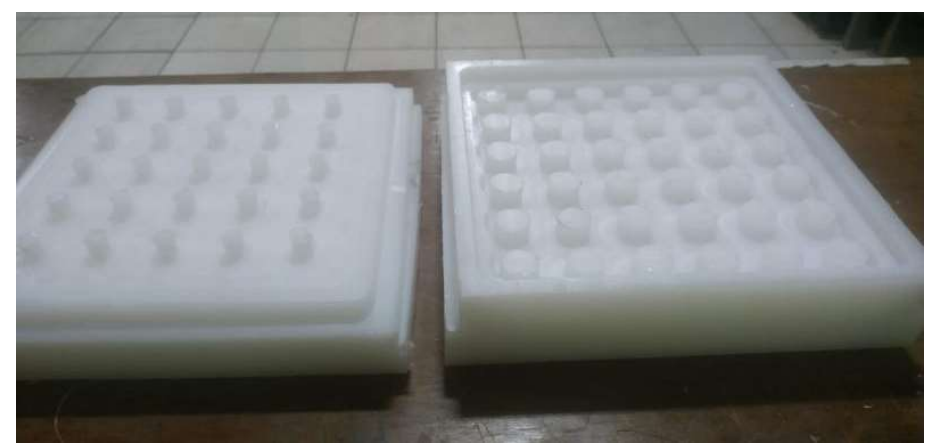

Gambar 2. Cetakan untuk membuat inti struktur sandwich berbentuk gelombang 
Cetakan untuk membuat inti dari struktur berlapis terdiri dari dua bagian, yaitu cetakan bagian bawah dan cetakan bagian atas. Pada saat pembuatan inti struktur berlapis, serat kaca diletakkan di atas cetakan bagian bawah dan kemudian dilumuri dengan resin. Setelah resin menyerap ke dalam serat, kemudian cetakan bagian atas ditutupkan di atas serat, sehingga serat kaca yang telah dilumuri resin akan terjepit di antara cetakan bawah dan cetakan atas. Posisi tonjolan-tonjolan pada cetakan atas dan cetakan bawah diatur sedemikian rupa hingga tonjolan-tonjolan itu saling mengisi ruang kosong yang ada pada cetakan pasangannya. Dengan bentuk pasangan cetakan seperti ini, maka didapatkan inti struktur berlapis dengan bentuk gelombang yang mendekati bentuk trapezoidal ke dua arah seperti yang telihat pada gambar 3.a dan gambar 3.b.

Bagian inti struktur berlapis dibuat dengan dua variasi jenis anyaman serat, yaitu WR400 dan WR600. Masing-masing jenis anyaman tersebut dibuat dengan dua variasi ketebalan dinding inti struktur berlapis, yaitu ketebalan dinding yang didapat dari pengunaan 1 lapis serat kaca dan 2 lapis serat kaca.

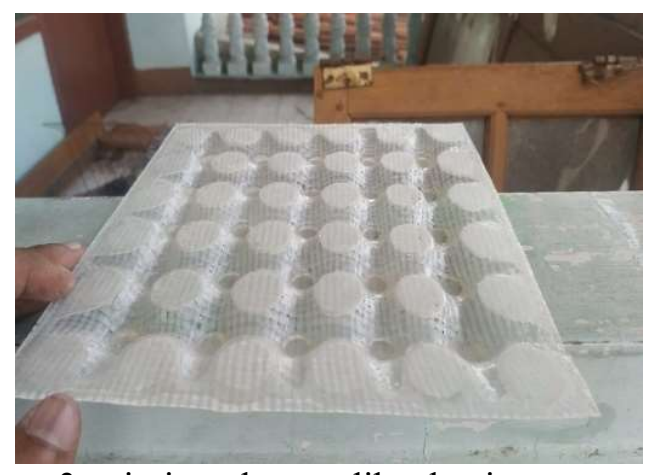

3.a. inti struktur terlihat bagian atas

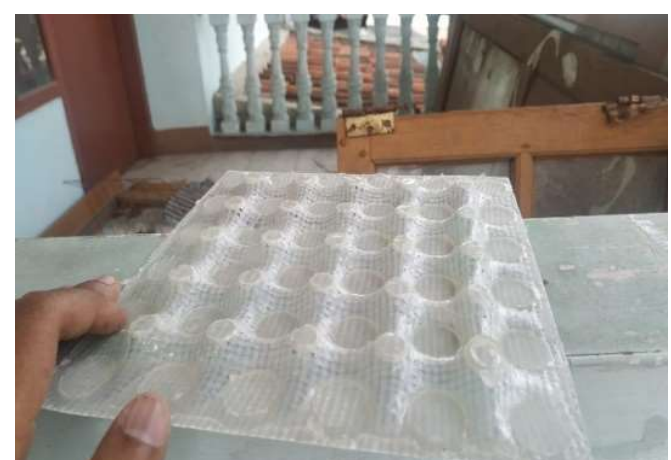

3.b. inti struktur terlihat bagian bawah

Gambar 3. inti struktur sandwich berbentuk gelombang hasil pencetakan

Lapisan kulit (skin) dibuat sama untuk semua spesimen panel, yaitu dari 1 lapis serat kaca WR400, agar perbandingan di antara semua panel terjadi secara imbang (proporsional) dan perbedaan yang terjadi di antara spesimen-spesimen panel betul-betul hanya merupakan efek dari perbedaan ketebalan dinding inti struktur sandwich. Bagian kulit dari struktur berlapis ini dibuat dengan menggunakan dua buah kaca tebal sebagai cetakan untuk mendapatkan kerataan yang baik. Inti struktur sandwich yang berbentuk gelombang trapezoidal selanjutnya disatukan dengan lapisan kulit bagian atas dan lapisan kulit bagian bawah sehingga diperoleh struktur berlapis seperti yang terlihat pada gambar 4

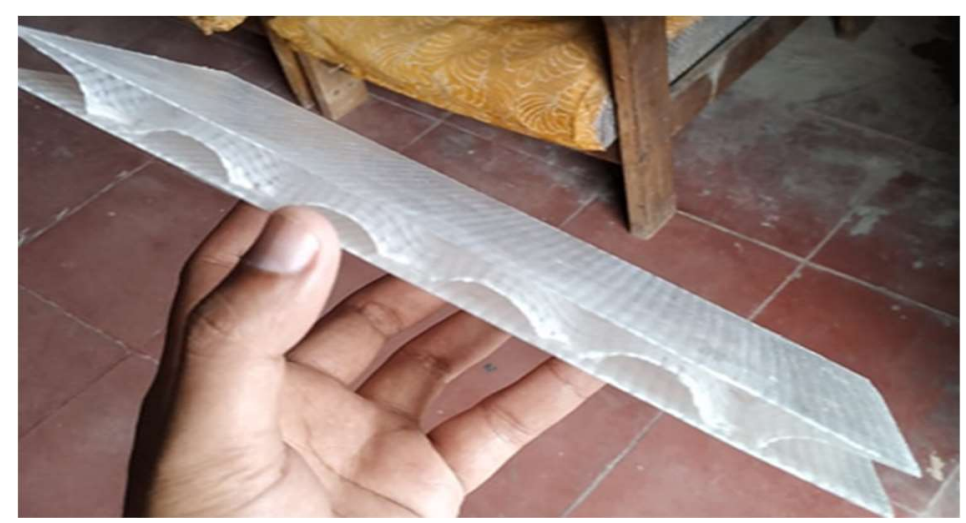

Gambar 4. Struktur berlapis dengan inti berbentuk gelombang 


\subsection{Pengujian Spesimen Struktur Berlapis}

Pengujian pada spesimen panel struktur berlapis ini terutama bertujuan untuk mendapatkan kekuatan bending (flexural strength) dan angka kekakuan (stiffness), disamping karakteristik mekanik lain yang dapat diperoleh melalui uji bending. Spesimen panel yang diuji memiliki ukuran panjang $200 \mathrm{~mm}$, lebar $100 \mathrm{~mm}$ dan tebal kira-kira $10 \mathrm{~mm}$. Penyesuaian ukuran panjang dan lebar specimen panel ini dilakukan dengan mengacu kepada standar pengujian untuk struktur berlapis ASTM C393-00 [5]. Pengujian spesimen panel struktur berlapis dilakukan dengan metoda uji bending dengan pembebanan terpusat di satu titik, tepat di tengah-tengah tumpuan seperti yang terlihat pada gambar 5. Jarak antara tumpuan $\left(\mathrm{L}_{1}\right)$ adalah $160 \mathrm{~mm}$ sedangkan beban berada tepat di tengah-tengah jarak antara tumpuan $\left(\mathrm{L}_{1} / 2\right)$. Uji bending dilakukan di atas mesin Gotech Testing Machine, Model GT-7001-LS10, seperti yang terlihat pada gambar 6 .

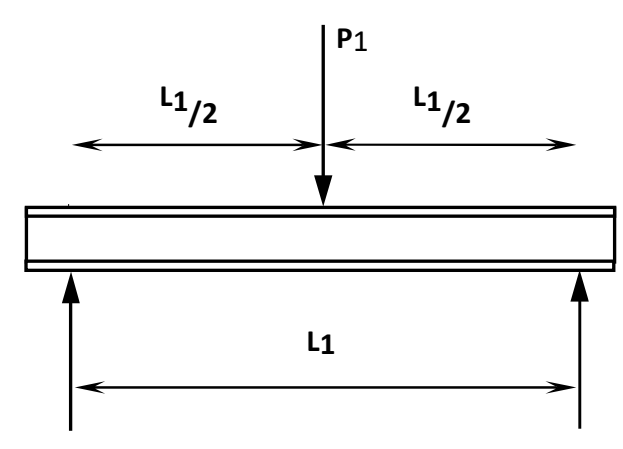

Gambar 5. Pembebanan satu titik [5]

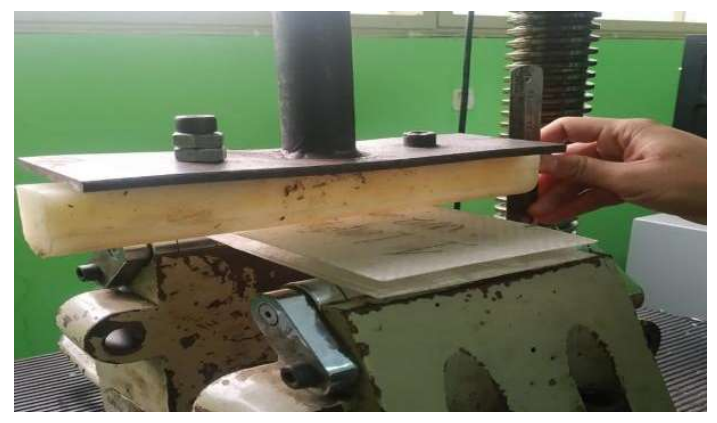

Gambar 6. Pengujian panel struktur berlapis menggunakan Gotech Testing Machine

\section{HASIL DAN PEMBAHASAN}

\subsection{Fenonema kegagalan pada spesimen struktur berlapis}

Pengujian bending dengan mesin Gotech Testing Machine, Model GT-7001-LS10 memberikan grafik beban terhadap defleksi seperti yang terlihat pada gambar 7, gambar 8, gambar 9 dan gambar 10.

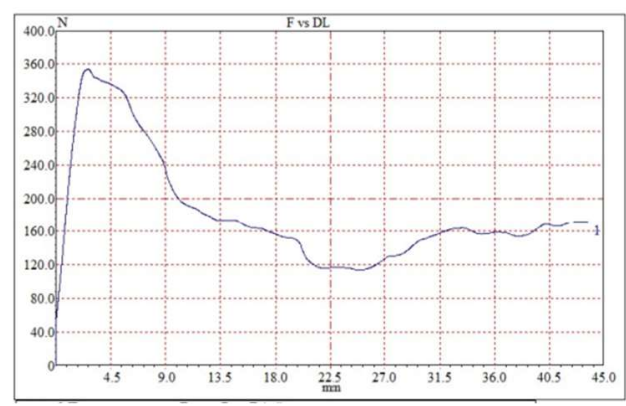

Gambar 7. Hasil Pengujian spesimen sandwich : 1 Lapis WR 400

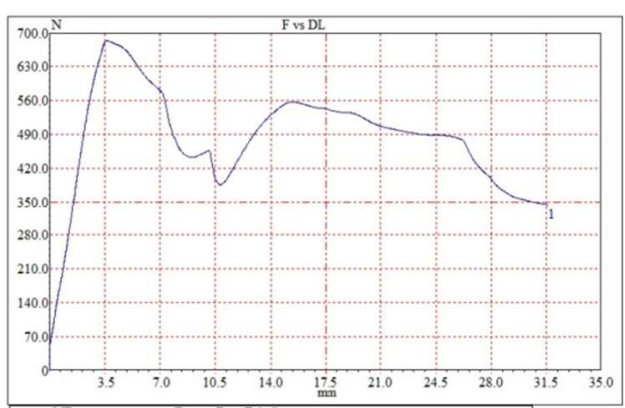

Gambar 8. Hasil Pengujian spesimen sandwich 2 Lapis WR 400 


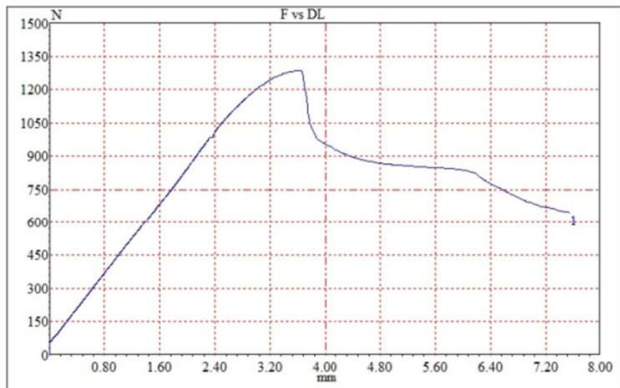

Gambar 9. Hasil Pengujian spesimen sandwich : 1 Lapis WR 600

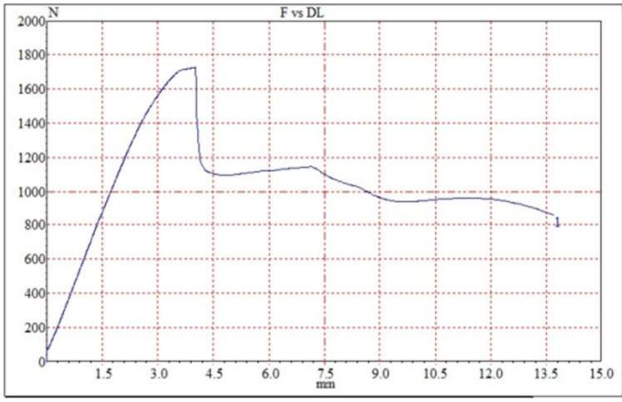

Gambar 10. Hasil Pengujian spesimen sandwich 2 Lapis WR 600

Grafik uji bending yang diperlihatkan oleh gambar 7, gambar 8 gambar 9 dan gambar 10 menunjukkan fenomena grafik yang mirip setelah spesimen melewati beban maksimum yang dapat ditahan, yaitu pola grafiknya tidak serta-merta jatuh, tapi tetap tertahan hingga terjadi defleksi yang agak panjang. Setelah melalui defleksi yang panjang, barulah spesimen stuktur berlapis tidak dapat menahan beban lagi dan patah. Grafik dengan bentuk seperti ini menunjukkan bahwa kegagalan dari struktur berlapis ini terjadi secara bertahap. Ketika satu sel dari inti struktur berlapis telah mengalami kegagalan, buckling atau berkerut, maka sel inti struktur berlapis yang lain akan menahan beban. Kegagalan struktur berlapis yang berupa lepasnya ikatan antara inti dengan kulit (skin) terjadi beberapa kali pada beberapa titik (sel inti) secara beruntun, sampai akhirnya spesimen benar-benar patah.

Defleksi maksimum yang terjadi pada spesimen panel stuktur berlapis sesaat sebelum spesimen benar-benar patah menunjukkan angka defleksi cukup besar, terutama pada spesimen yang dibuat dengan serat kaca WR400. Hal ini menunjukkan bahwa spesimen struktur berlapis dengan inti berbentuk gelombang trapezoidal berbahan komposit serat kaca memiliki sifat ulet dan lentur yang cukup tinggi dan tidak mudah pecah.

\subsection{Beban maksimum}

Beban maksimum yang dapat ditahan oleh spesimen panel struktur berlapis serta defleksi maksimum yang terjadi pada masing-masing specimen panel saat mendapat beban maksimum terlihat pada tabel 1.

Tabel 1 Hasil Pengujian

\begin{tabular}{cccc}
\hline $\begin{array}{c}\text { Variasi } \\
\text { Lapisan }\end{array}$ & $\begin{array}{c}\text { Berat } \\
\text { spesimen } \\
(\mathrm{g})\end{array}$ & $\begin{array}{c}\text { Beban } \\
\text { maksimum } \\
(\mathrm{kgf})\end{array}$ & $\begin{array}{c}\delta \text { Defleksi } \\
\text { maksimum } \\
(\mathrm{mm})\end{array}$ \\
\hline Fiberglass WR 400 & & & \\
\hline 1 lapis & 79 & 36,08 & 45 \\
\hline 2 lapis & 130 & 69,69 & 35 \\
\hline Fiberglass WR 600 & & & \\
\hline 1 lapis & 100 & 129,33 & 8 \\
\hline 2 lapis & 160 & 176,05 & 14 \\
\hline
\end{tabular}

Tabel 1 menunjukkan bahwa kemampuan menahan beban dari spesimen panel struktur berlapis dengan inti yang terbuat dari bahan komposit serat kaca WR-600 lebih tinggi daripada spesimen panel struktur berlapis dengan inti yang terbuat dari bahan komposit serat kaca WR-400. Hal ini sudah dapat diduga karena serat kaca WR-600 memiliki ketebalan yang lebih tinggi daripada serat kaca WR-400. Dengan ketebalan yang lebih tinggi, maka serat kaca WR-600 memiliki luas 
penampang lintang yang lebih besar dan tentunya memiliki kemampuan untuk menahan beban yang lebih besar.

Perbedaan ketebalan dinding inti struktur dan luas penampang lintang struktur dari masingmasing spesimen panel struktur sandwich memang tidak terlihat pada tabel 1, tapi indikasi adanya penambahan ketebalan dinding inti struktur dan penambahan luas penampang lintang struktur ditunjukkan dengan adanya penambahan bobot spesimen panel struktur sandwich. Dengan dimensi spesimen panel struktur sandwich yang relatif sama, maka dapat dipastikan bahwa penambahan bobot spesimen berasal dari peningkatan ketebalan dinding inti struktur sandwich dan luas penampang lintang strukturnya.

Pada penggunaan jumlah serat yang sama untuk inti struktur sandwich, yaitu 1 lapis serat kaca, beban maksimum yang dapat ditahan oleh struktur berlapis yang menggunakan serat WR600 adalah 3,6 kali lebih besar daripada beban maksimum yang dapat ditahan oleh struktur berlapis yang menggunakan serat WR400. Hal ini terlihat jelas pada gambar 11. Di sisi lain, spesimen panel dengan inti yang dibuat dari serat WR600 memiliki bobot 1,3 kali lebih berat daripada bobot spesimen panel dengan inti yang dibuat dari WR400. Data tersebut menunjukkan adanya peningkatan kemampuan menahan beban yang signifikan dengan hanya penambahan bobot yang relatif kecil, yaitu terjadi peningkatan kemampuan menahan beban sebesar 3,6 kali dengan penambahan berat yang hanya sebesar 1.3 kali.

\section{Beban Maksimum}

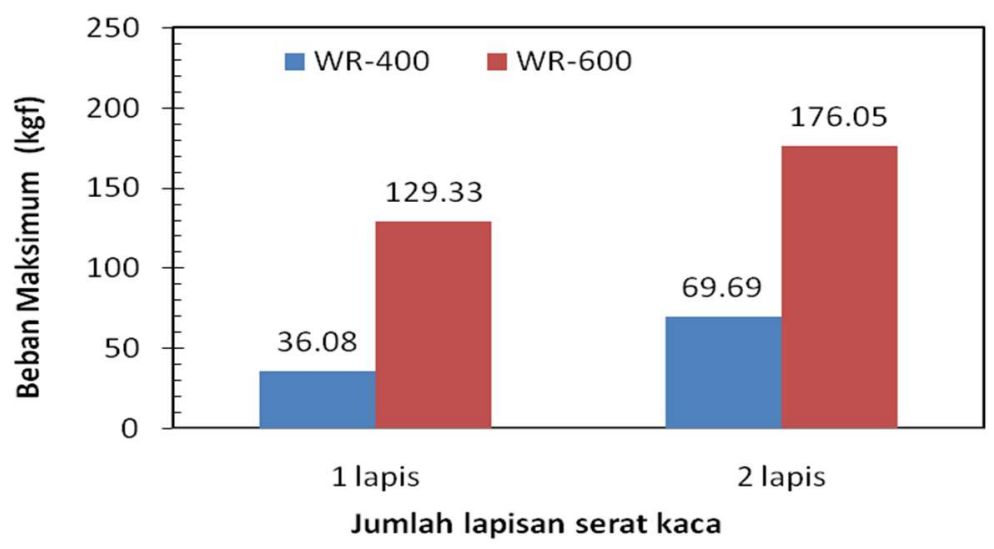

Gambar 11. Beban maksimum yang mampu ditahan struktur berlapis berbahan komposit serat kaca dengan inti benbentuk gelombang trapezoidal dua arah

Pada penggunaan jumlah serat sebanyak 2 lapis serat kaca untuk pembuatan inti struktur sandwich, spesimen panel yang menggunakan serat WR600 memiliki kemampuan menahan beban maksimum 2,5 lebih besar daripada spesimen panel yang menggunakan serat WR400. Perbedaan di antara kedua spesimen panel ini terlihat jelas pada gambar 11. Dari sisi bobot, spesimen yang menggunakan serat WR600 lebih berat 1,2 kali lebih besar daripada spesimen yang menggunakan serat WR400. Artinya dengan penambahan bobot sebesar 1,2 kali, kemampuan menahan beban dari spesimen struktur berlapis ini meningkat menjadi 2,5 kali.

Gambar 11 juga memperlihatkan bahwa pada penggunaan jenis serat yang sama, penambahan jumlah lapisan serat yang digunakan untuk membuat inti struktur memberikan peningkatan kemampuan menahan beban maksimum. Penambahan jumlah lapisan serat yang digunakan untuk membuat inti struktur tentu akan menambah ketebalan dinding inti struktur, yang artinya luas penampang lintang struktur juga akan bertambah sehingga kemampuan untuk menahan beban dari struktur sandwich ini juga akan meningkat. 
Berbeda dengan peningkatan kemampuan menahan beban maksimum yang signifikan pada variasi penggunaan jenis serat WR400 dan WR600, pengaruh penambahan jumlah lapisan serat kaca pada inti struktur berlapis tidak menunjukkan peningkatan kemampuan menahan beban maksimum secara signifikan. Pada spesimen yang menggunakan serat WR400, penambahan berat spesimen sebesar 1,6 kali hanya memberikan peningkatan kemampuan untuk menahan beban maksimum sebesar 1,9 kali. Pada spesimen yang menggunakan serat WR600, penambahan berat spesimen sebesar 1,6 kali hanya memberikan peningkatan kemampuan untuk menahan beban maksimum sebesar 1,4 kali.

Jika spesimen-spesimen panel struktur sandwich ini dibandingkan dalam hal rasio beban maksimum terhadap berat (maksimum load-to-weight ratio), maka angka rasio terbesar didapatkan pada spesimen panel struktur sandwich dengan inti struktur yang dibuat dengan 1 lapis serat WR600, yaitu sebesar 1.293,30 kgf/kgm. Angka rasio beban maksimum terhadap berat dari masing-masing spesimen panel terlihat pada tabel 2 .

Tabel 2 Perhitungan rasio kemampuna menahan beban maksimum terhadap berat

\begin{tabular}{cccc}
\hline $\begin{array}{c}\text { Variasi Lapisan } \\
\text { Serat kaca }\end{array}$ & $\begin{array}{c}\text { Berat } \\
\text { spesimen } \\
(\mathrm{g})\end{array}$ & $\begin{array}{c}\text { Beban } \\
\text { maksimum } \\
(\mathrm{kgf})\end{array}$ & $\begin{array}{c}\text { maksimum load to } \\
\text { weight ratio } \\
(\mathrm{kgf} / \mathrm{kgm})\end{array}$ \\
\hline Serat kaca WR400 - 1 lapis & 79 & 36,08 & 456,71 \\
\hline Serat kaca WR400 - 2 lapis & 130 & 69,69 & 536,08 \\
\hline Serat kaca WR600-1 lapis & 100 & 129,33 & $1.293,30$ \\
\hline Serat kaca WR600-2 lapis & 160 & 176,05 & $1.100,31$ \\
\hline
\end{tabular}

\subsection{Kekuatan bending spesimen struktur berlapis}

Kekuatan bending (Flexural strength) dari specimen panel struktur berlapis dalam penelitian ini dihitung berdasarkan data beban maksimum hasil uji bending yang terlihat pada tabel 2, serta data-data lain berupa jarak antara tumpuan (L) pada saat pengujian, konstanta $\mathrm{C}$ dan momen inersia penampang yang diperoleh dari pengukuran detail dimensi specimen panel struktur berlapis. Kekuatan bending maksimum dari spesimen struktur berlapis dapat diketahui dengan menggunakan persamaan tegangan pada simple beam, yaitu $\sigma=\mathrm{M} \cdot \mathrm{C} / \mathrm{I}_{\mathrm{zz}}[6]$. Angka kekuatan bending maksimum untuk setiap variasi penggunan jenis serat dan variasi jumlah lapisan serat pada inti stuktur terlihat pada tabel 3 .

Tabel 3 Perhitungan kekuatan bending maksimum

\begin{tabular}{cccccc}
\hline $\begin{array}{c}\text { Variasi jenis serat - } \\
\text { variasi jumlah } \\
\text { lapisan serat }\end{array}$ & $\begin{array}{c}\text { Beban } \\
\text { maksimum } \\
(\mathrm{kgf})\end{array}$ & $\begin{array}{c}\text { Jarak antar } \\
\text { tumpuan } \\
(\mathrm{L})\end{array}$ & $\mathrm{C}$ & $\mathbf{I}_{z z}$ & $\sigma_{\max }$ \\
\hline WR400 - 1 lapis & 36,08 & 160.00 & 6,80 & 10.158 & 0,966 \\
\hline WR400 - 2 lapis & 69,69 & 160.00 & 7,30 & 12.384 & 1,643 \\
\hline WR600 - 1 lapis & 129,33 & 160.00 & 7,10 & 11.379 & 3,228 \\
\hline WR600 - 2 lapis & 176,05 & 160.00 & 7,70 & 13.832 & 3,920 \\
\hline
\end{tabular}

Kekuatan bending yang dimiliki oleh spesimen panel struktur berlapis dengan inti yang dibuat dari bahan komposit serat kaca WR-600 lebih besar daripada kekuatan bending spesimen panel struktur berlapis dengan inti yang dibuat dari bahan komposit serat kaca WR-400. Penggunaan lapisan serat yang lebih banyak pada pembuatan inti struktur juga memberikan efek terhadap peningkatan kekuatan bending dari spesimen panel struktur berlapis. Angka kekuatan bending yang lebih besar pada penggunaan serat WR600 dan penggunaan lapisan serat yang lebih banyak terlihat pada tabel 3 . 
Adalah sangat logis jika penggunaan serat yang lebih tebal (WR600) dan pengunaan jumlah lapisan serat yang lebih banyak pada pembuatan inti struktur akan meningkatkan angka kekuatan bending. Hal ini bisa terjadi karena serat yang lebih tebal dan jumlah lapisan serat yang lebih banyak akan meningkatkan ketebalan dinding inti struktur dan menambah luas penampang lintang struktur, sehingga spesimen panel struktur sandwich akan memiliki kemampuan untuk menahan beban yang lebih besar. Angka kekuatan bending sebenarnya juga ditentukan oleh besar momen inersia penampang $\left(\mathrm{I}_{\mathrm{zz}}\right)$, dimana besar momen inersia penampang juga meningkat sejalan dengan peningkatan luas penampang lintang sebuah batang. Tapi jika dilihat pada tabel 3, bahwa kenaikan kemampuan menahan beban dari spesimen panel struktur berlapis lebih besar dibandingkan dengan peningkatan angka momen inersia penampangnya. Dengan demikian, dapat dipastikan bahwa pengunaan serat yang lebih tebal (WR600) dan penggunaan jumlah lapisan serat yang lebih banyak untuk pembuatan inti struktur sandwich akan berdampak kepada kenaikan angka kekuatan bending.

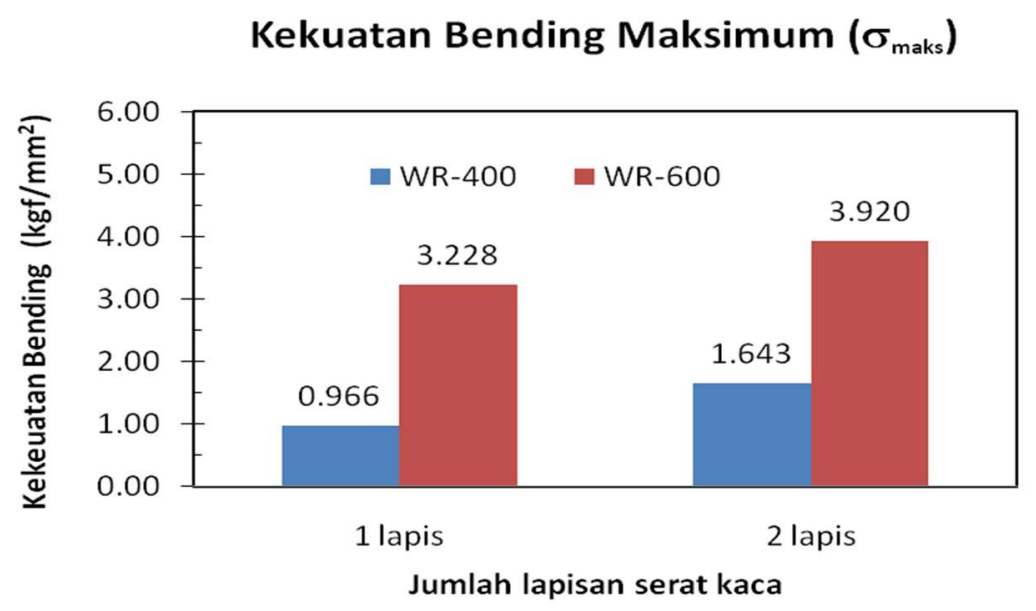

Gambar 12. Kekuatan bending struktur berlapis berbahan komposit serat kaca dengan inti benbentuk gelombang trapezoidal dua arah

Penggunaan serat yang lebih tebal (WR600 dibandingkan WR400) untuk pembuatan inti struktur sandwich memberikan efek yang lebih besar terhadap peningkatan kekuatan bending daripada penggunaan lapisan serat yang lebih banyak (1 lapis dan 2 lapis). Hal ini terlihat jelas pada grafik dalam gambar 12. Penggunaan 1 lapis serat kaca WR600 pada pembuatan inti struktur sandwcih memberikan angka kekuatan bending 3,3 kali lebih besar daripada penggunaan 1 lapis serat kaca WR400. Pada penggunaan 2 lapis serat kaca untuk pembuatan inti struktur sandwcih, specimen panel dengan bahan serat WR600 memiliki kekuatan bending 2,4 lebih besar daripada specimen panel dengan bahan serat WR400. Pada penggunaan jenis serat yang sama, yaitu WR400, penggunaan 2 lapis serat kaca untuk pembuatan inti struktur sandwich menghasilkan peningkatan angka kekuatan bending sebesar 1,7 kali daripada penggunaan 1 lapis serta kaca. Dan untuk penggunaan serat jenis WR600, penggunaan 2 lapis serat kaca untuk pembuatn inti struktur sandwich memberikan kenaikan angka kekuatan bending sebesar 1,2 kali dibandingkan penggunaan 1 lapis serat kaca.

Jika dibandingkan dengan bobot masing-masing specimen panel maka, semakin terlihat bahwa penggunaan jenis serat yang lebih tebal (WR600 dibandingkan WR400) untuk pembuatan inti struktur sandwich memberikan peningkatan perbandingan kekuatan bending terhadap berat (flexural strength-to-weight ratio) yang lebih signifikan dibandingkan penggunaan lapisan serat yang lebih banyak (1 lapis dan 2 lapis). Bahkan pada spesimen panel yang dibuat dengan serat WR600, penggunaan 2 lapis serat tidak meningkatkan rasio kekuatan bending terhadap beratnya. Hal ini terlihat pada tabel 4. 
Spesimen panel dengan inti struktur sandwich yang dibuat dengan serat kaca WR600 memiliki angka flexural strength-to-weight ratio yang lebih besar 2,6 kali dibandingkan specimen panel dengan inti struktur sandwich yang dibuat dengan serat kaca WR400 untuk penggunaan 1 lapis serat. Pada penggunaan 2 lapis serat, spesimen panel dengan inti struktur sandwich yang dbuat dengan serat kaca jenis WR600 memiliki angka flexural strength-to-weight ratio yang 1,9 kali lebih besar dibanding spesimen panel dengan inti struktur sandwich yang dbuat dengan serat kaca jenis WR400.

Untuk spesimen dengan inti struktur yang dibuat dengan bahan serat yang sama, yaitu WR400, angka flexural strength-to-weight ratio dari spesimen panel dengan inti struktur yang dibuat dengan 2 lapis serat kaca hampir tidak berbeda dengan spesimen panel yang memiliki inti struktrur yang dibuat dengan 1 lapis serat kaca. Bahkan pada spesimen dengan inti struktur yang dibuat dengan serat WR600, penggunaan 2 lapis serat menghasilkan angka flexural strength-toweight ratio yang lebih rendah daripada pengguinaan 1 lapis serat. Artinya penambahan jumlah serat yang dipakai untuk pembuatan inti struktur berbentuk gelombang belum tentu meningkatkan angka flexural strength-to-weight ratio karena penambahan jumlah lapisan serat pada inti struktut berlapis juga akan berdampak kepada penambahan berat. Jika penambahan berat spesimen panel struktur sandwich yang terjadi akibat penambahan jumlah lapisan serat lebih besar dari peningkatan kekuatan bending maka angka flexural strength-to-weight ratio akan menjadi lebih kecil.

Tabel 4 Perhitungan rasio kekuatan bending terhadap berat

\begin{tabular}{cccc}
\hline $\begin{array}{c}\text { Variasi jenis serat - variasi } \\
\text { jumlah lapisan serat }\end{array}$ & $\begin{array}{c}\text { Berat } \\
\text { spesimen } \\
(\mathrm{g})\end{array}$ & $\begin{array}{c}\text { Kekuatan } \\
\text { bending } \\
\left(\mathrm{kgf} / \mathrm{mm}^{2}\right)\end{array}$ & $\begin{array}{c}\text { Flexural Strength } \\
\text { to weight ratio } \\
\left(\mathrm{kgf} / \mathrm{mm}^{2}\right) / \mathrm{kgm}\end{array}$ \\
\hline Serat kaca WR400 - 1 lapis & 79 & 0,966 & 12,229 \\
\hline Serat kaca WR400 - 2 lapis & 130 & 1,643 & 12,640 \\
\hline Serat kaca WR600 - 1 lapis & 100 & 3,228 & 32,278 \\
\hline Serat kaca WR600 - 2 lapis & 160 & 3,920 & 24,501 \\
\hline
\end{tabular}

Adapaun angka rasio kekuatan bending terhadap berat (flexural strength-to-weight ratio) yang terbaik ditunjukkan oleh spesimen panel struktur sandwich dengan inti struktur yang dibuat dengan 1 lapis serat kaca jenis WR600, yaitu dengan angka 32,278 ( kgf $\left./ \mathrm{mm}^{2}\right) / \mathrm{kgm}$.

\subsection{Kekakuan spesimen struktur berlapis}

Kekakuan (stiffness) yang didapatkan dari pengujian bending dalam penelitian ini adalah kekakuan bending (bendng stiffness). Kekakuan bending dari spesimen struktur berlapis dapat diketahui dengan cara membagi beban yang terjadi pada spesimen panel struktur berlapis dengan besar defleksi yang terjadi pada saat spesimen panel tersebut mendapat beban, melalui persamaan $\mathrm{K}=\mathrm{F} / \delta[6]$. Kekakuan struktur berlapis dihitung pada daerah elastis dari kurva grafik uji bending. Angka kekakuan spesimen untuk setiap variasi penggunan jenis serat dan variasi jumlah lapisan dapat dilihat pada gambar 13 . 


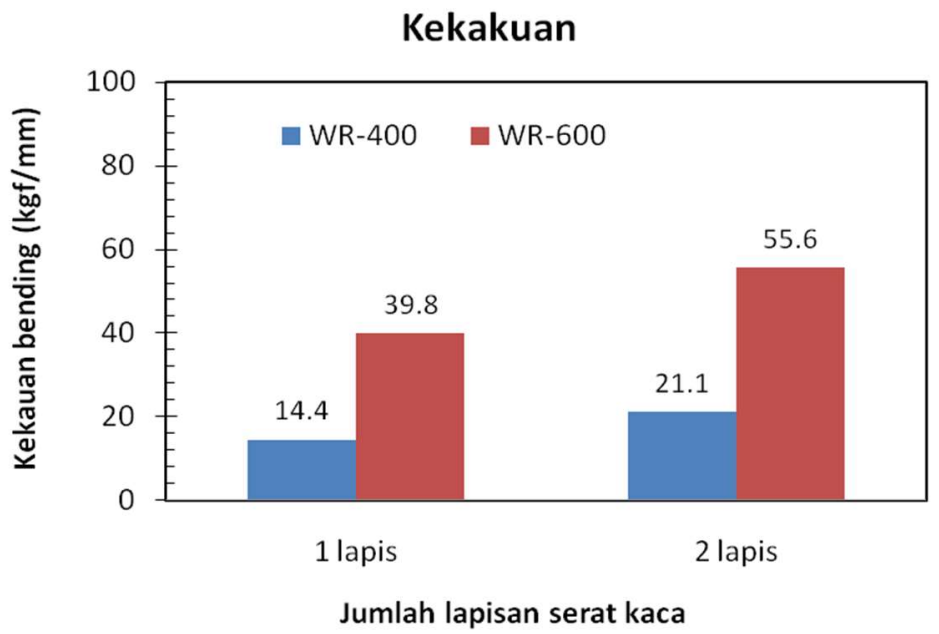

Gambar 13. Kekakuan bending struktur berlapis berbahan komposit serta kaca

Panel struktur berlapis dengan inti struktur yang dibuat dengan bahan komposit fiberglass WR400 memiliki kekakuan lebih rendah dibandingkan panel struktur berlapis dengan inti struktur yang dibuat dengan bahan fiberglass WR600 dengan jumlah lapisan dinding inti yang sama. Angka kekakuan spesimen struktur berlapis dengan inti struktur yang dibuat dengan 1 lapis serat kaca WR600 lebih besar 2,8 kali daripada angka kekakuan spesimen struktur berlapis dengan inti struktur yang dibuat dengan 1 lapis serat kaca WR400. Untuk aplikasi 2 lapis serat kaca pada inti struktur, kekakuan spesimen struktur berlapis yang dibuat dengan bahan serat WR600 memiliki angka kekakuan 2,6 kali lebih besar daripada spesimen struktur berlapis yang dibuat dengan bahan serat WR400.

Peningkatan angka kekakuan sebagai dampak dari penambahan jumlah lapisan pada dinding inti struktur berlapis tidak sebesar dampak yang diberikan dari penggunaan serat yang berbeda. Peningkatan kekakuan pada spesimen dengan inti struktur yang dibuat dengan 2 lapis serat kaca WR400 adalah 1,5 kali lebih besar daripada spesimen dengan inti struktur yang dibuat dengan 1 lapis serat kaca. Peningkatan kekakuan pada spesimen dengan inti struktur yang dibuat dengan 2 lapis serat kaca WR600 adalah 1,4 kali lebih besar daripada spesimen dengan inti struktur yang dibuat dengan 1 lapis serat kaca.

Secara teoritk, kekakuan dari suatu struktur akan ikut ditentukan oleh besar momen inersia penampang struktur tersebut. Momen inersia penampang yang lebih besar akan membuat kekakuan struktur menjadi lebih tinggi. Data momen inersia penampang pada tabel 3 mengkonfirmasi bahwa penggunanan serat yang lebih tebal dan penggunaan jumlah lapisan serat yang lebih banyak pada dinding inti struktur berlapis telah memberikan efek kepada peningkatan angka momen inersia penampang, yang pada gilirannya akan berdampak juga kepada peningkatan kekakuan struktur berlapis.

Performa kekakuan suatu struktur juga dapat dibandingkan terhadap bobot dari struktur tersebut dalam bentuk rasio kekakuan terhadap berat (stiffness-to-weight ratio). Dengan menggunakan data pengujian dan perhitungan kekakuan, dapat dihitung rasio kekakuan terhadap berat untuk setiap spesimen panel struktur sandwich seperti yang tercantum dalam tabel 5. Pada tabel tersebut dapat dilihat bahwa angka terbaik dari rasio kekakuan terhadap berat ditunjukkan oleh spesimen panel struktur sandwich dengan inti struktur yang dibuat dari 1 lapis serat kaca jenis WR600, yaitu dengan angka rasio sebesar 398,00 (kgf/mm)/kgm. 
JURNAL REKAYASA ENERGI DAN MEKANIKA - Vol. 01 No. 02 (2021)

Tabel 5 Perhitungan rasio kekakuan terhadap berat

\begin{tabular}{cccc}
\hline $\begin{array}{c}\text { Variasi jenis serat - variasi } \\
\text { jumlah lapisan serat }\end{array}$ & $\begin{array}{c}\text { Berat } \\
\text { spesimen } \\
(\mathrm{g})\end{array}$ & $\begin{array}{c}\text { Kekakuan } \\
(\mathrm{kgf} / \mathrm{mm})\end{array}$ & $\begin{array}{c}\text { Stiffness to weight } \\
\text { ratio } \\
(\mathrm{kgf} / \mathrm{mm}) / \mathrm{kgm}\end{array}$ \\
\hline Serat kaca WR400 - 1 lapis & 79 & 14,4 & 182,28 \\
\hline Serat kaca WR400 - 2 lapis & 130 & 21,1 & 162,31 \\
\hline Serat kaca WR600 - 1 lapis & 100 & 39,8 & 398,00 \\
\hline Serat kaca WR600 - 2 lapis & 160 & 55,6 & 347,50 \\
\hline
\end{tabular}

\section{KESIMPULAN}

Penelitian yang dilakukan menunjukkan bahwa penggunaan cetakan dan metoda hand lay-up cukup efektif untuk pembuatan struktur berlapis dengan inti berbentuk gelombang trapezoidal, terutama untuk pembuatan inti struktur berlapis. Hal ini terlihat dari kualitas inti cetakan yang baik serta dengan bentuk dan dimensi yang cukup konsisten.

Performa dalam hal kekuatan menahan beban maksimum telah didapatkan untuk masing-masing variasi spesimen. Spesimen dengan inti struktur yang dibuat dari bahan komposit serat kaca WR400 menunjukkan kemampuan dapat menahan beban maksimum sampai sebesar 36,08 kgf untuk penggunaan jumlah lapisan serat sebanyak 1 lapis dan 69,69 kgf untuk penggunaan jumlah lapisan serat sebanyak 2 lapis. Spesimen dengan inti struktur yang dibuat dari bahan komposit serat kaca WR600 menunjukkan kemampuan menahan beban maksimum sampai sebesar 129,33 kgf untuk penggunaan jumlah lapisan serat sebanyak 1 lapis dan 176,05 kgf untuk pengunaan jumlah lapisan serat sebanyak 2 lapis. Rasio beban maksimum terhadap berat (maksimum load-to weight ratio) terbesar diperoleh pada spesimen panel struktur sandwich dengan inti struktur yang dibuat dengan serat WR600 dengan jumlah lapisan serat 1 lapis, yaitu sebesar 1.293,30 kgf/kgm.

Kekuatan bending (flexural strength) terbesar yang dapat dicapai oleh spesimen panel struktur berlapis dengan inti berbentuk gelombang trapozoidal dua arah adalah sebesar 3,920 kgf $/ \mathrm{mm}^{2}$ yang dicapai oleh specimen dengan inti yang dibuat dengan 2 lapis serat WR600. Specimen dengan kekuatan bending terkecil adalah spesimen dengan inti yang dibuat dengan 1 lapis serat WR400, yaitu $0.966 \mathrm{kgf} / \mathrm{mm}^{2}$. Specimen dengan inti yang dibuat dengan 2 lapis serta WR400 memiliki angka kekuatan bending sebesar $1,643 \mathrm{kgf} / \mathrm{mm}^{2}$ dan spesimen dengan inti yang dibuat dengan 1 lapis serta WR600 memiliki angka kekuatan bending sebesar 3,228kgf $/ \mathrm{mm}^{2}$. Rasio kekuatan bending terhadap berat (flexural sttrength-to-weight ratio) terbesar didapatkan pada spesimen dengan inti yang dibuat dengan 1 lapis serat WR600, yaitu sebesar 32,278 $\left(\mathrm{kgf} / \mathrm{mm}^{2}\right) / \mathrm{kgm}$.

Struktur berlapis dengan inti yang dibuat dari bahan komposit serat kaca WR400 menunjukkan angka kekakuan sebesar 14,4 kgf/mm untuk penggunaan jumlah lapisan serat sebanyak 1 lapis dan 21,1 kgf/mm untuk pengunaan jumlah lapisan serat sebanyak 2 lapis. Spesimen struktur berlapis dengan inti yang dibuat dari bahan komposit serat kaca WR600 menunjukkan angka kekakuan sebesar 39,8 kgf/mm untuk penggunaan jumlah lapisan serat sebanyak 1 lapis dan 55,6 $\mathrm{kgf} / \mathrm{mm}$ untuk pengunaan jumlah lapisan serat sebanyak 2 lapis. Rasio kekakuan terhadap berat (stiffness-to-weight ratio) terbesar didapatkan pada spesimen panel struktur sandwich dengan inti struktur yang dibuat dengan 1 lapis serat WR600, yaitu dengan angka sebesar 398,00 $(\mathrm{kgf} / \mathrm{mm}) / \mathrm{kgm}$.

Data hasil pengujian serta data hasil olahan dari data pengujian menunjukkan bahwa penggunakan jenis anyaman (WR : Woven Roving) serat kaca yang lebih tebal memberikan efek yang lebih signifikan terhadap peningkatan kemampuan menahan beban maksimum, kekuatan bending serta kekakuan daripada penggunaan jumlah lapisan serat yang lebih banyak. Dan jika dilihat dari rasio beban maksimum terhadap berat (maksimum load-to-weigth ratio), rasio kekuatan bending 
terhadap berat (flexural strength-to-weight ratio), serta rasio kekakuan terhadap berat (stiffnessto-weigth ratio) maka performa terbaik ditunjukkan oleh panel struktur berlapis (sandwich structure) dengan inti yang dibuat dari 1 lapis serat kaca WR600.

\section{DAFTAR PUSTAKA}

[1] Chang, Wan-Shu, Edward Venstel, Ted Krauthammer, Joby John (2005), "Bending Behavior of corrugated-core Sandwich Plates", Composite Structure, Volume 70, Issue 1. August 2005, pp 81-89.

[2] Tumino, Davide, Tommaso Ingrassia, Vicenzo Nigrelli, Giuseppe Pitarresi, Vicednzo Urso Miano (2014), "Mechanical behavior of a sandwich with corrugated GRP core: numerical modeling and experimental validation", Frattura ed Integrità Strutturale, 30 (2014) pp 317326; DOI: 10.3221/IGF-ESIS.30.39.

[3] Zaid, Z. M., M.R.M. Rejab and N.A.N Mohamed (2016), "Sandwich Structure Based On Corrugated-Core: A Review”, MATEC Web of Conferences, volume 74, 00029 (2016)

[4] Hou, Shujuan, Shuyun Zhao, Lili Ren, Xu Han, Qing Li (2013), "Crashworthiness Optimization of Corrugated Sandwich Panels”, Material \& Design, olume 51, October 2013, pp 1071-1084.

[5] Anonim, ASTM. (2000) ASTM C393-00 -Standard Test Method for Flexural Properties Of Sandwich Constructions.

[6] Mott, Robert L., (2002) “Applied Strength of Materials", $4^{\text {th }}$ Edition, Prentice-Hall, New jersey. 